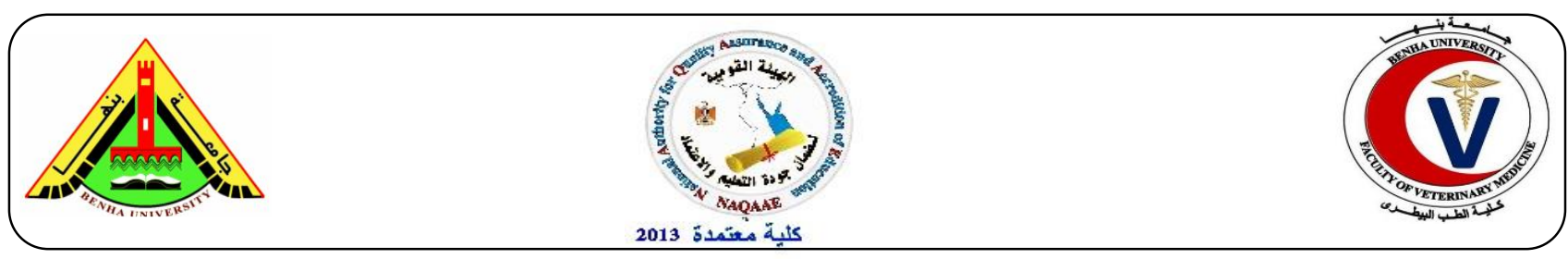

\title{
Ameliorative Effects of Lycopene against Boldenone Undecylenate Toxicity in Albino Rats
}

\author{
Sabra H.M., El-Shawarby R.M., Abosalem M., Nabila M. A., Ibrahim S.S. \\ Department of Forensic Medicine \& Toxicology. Faculty of Veterinary. Medicine. Benha \\ University.
}

\section{A B S T R A C T}

Although anabolic androgenic steroids like boldenone (BOL) may increase lean muscle mass, strength, and the ability to train longer and harder, the serious side effects of steroid are many and may not be reversible. So, the present study was designed to investigate the role of lycopene in improving the oxidative stress of boldenone in male albino rats. Twenty eight male adult rats were equally divided into four groups. $1^{\text {st }}$ group (control) that received olive oil once a week $(5 \mathrm{mg} / \mathrm{kg}$ intramuscularly). $2^{\text {nd }}$ group includes rats received lycopene daily (orally, $60 \mathrm{mg} / \mathrm{kg}$ body weight). $3^{\text {rd }}$ group includes animals that received intramuscular injections of boldenone once a week $(5 \mathrm{mg} / \mathrm{Kg}$ body weight). $4^{\text {th }}$ group was co-treated with boldenone and lycopene with the same previous doses of both, the experiment extended for 5 weeks. Intramuscular injection of rats with caused significant increase in total weight gain (TWG), serum total protein and globulin, malandialdehyde (MDA), Lactate dehydrogenase (LDH), creatinine kinase (CK), total protein in skeletal muscle, when compared with the control group. On the other hand, a significant decrease in albumin, Albumin/Globulin (AlG) ratio and superoxide dismutase (SOD) in boldenone group when compared with the control group. Also, the result of rats administered lycopene plus Boldenone (group4) showed marked improvement in all tested parameters, these findings may be attributed to that Lycopene has an effect on regulation of intracellular gap- junction communication, genes function regulation, modulation of various metabolic pathways of xenobiotic, hormone and immune modulation. These findings suggested that misuse of boldenone may contribute to a continuous tissue damage, so young people -especially- should be careful if they want to use boldenone to enhance their strength and endurance or if they want to use it in the farm animal as growth promoter. This showed that the desired dose of boldenone can safely be used with lycopene in improving the oxidative stress of boldenone.

Key words: Boldenone toxicity, Lycopene, Oxidative stress, Antioxidants, Liver, Heart.

\section{(http://www.bvmj.bu.edu.eg)}

(BVMJ-35(2): 237-249, 2018)

\section{INTRODUCTION}

Boldenone (1, 4-androstadiene-17beta-ol3-one; BOL) and its precursor boldenone are used as anabolic steroids in livestock
(Cannizzo et al; 2007). BOL is one of anabolic steroids (synthetic androgen hormone) that derived from testosterone, 
differs from testosterone by only one double bond at the 1-position (Zedan et al; 2014). BOL has a very long half-life and can show up on a steroid test for up to 1.5 years. BOL has been detected in untreated animals of several animal species (De Brabender et al 2004). BOL has been developed for veterinary use. BOL improves growth and feed conversion in veal calves and therefore might be used illegally to achieve more efficient meat production (Soma et al; 2007). Boldenone has dual effects on humans, both directly and indirectly; directly as injection to build muscles and indirectly as through consuming meat of animals that where treated with boldenone. In addition to the growth promoting effects, anabolic steroids have been shown to adversely affect the cardiovascular, hepatic, kidney and endocrine systems (Tousson et al; 2012b). A major side effect of anabolic- androgenic steroids therapy is hepatotoxicity, including elevated levels of liver enzymes, cholestatic jaundice, peliosishepatis and various neoplastic lesions (Shahidi 2001). Boldenone increases muscle size due to promotion of positive nitrogen balance by stimulating protein production and reducing protein destruction, moreover it produces retention of body water, nitrogen, sodium, potassium and calcium ions (Tousson et al; 2012a). Injection of the anabolic steroid boldenone induced changes in oxidative stress biomarker levels and antioxidant defense systems in rabbit liver and kidney (Mottram and George, 2000).

Lycopene is a bright red carotenoid pigment found in tomatoes and other red fruits (Britton, 1995). Lycopene is an important intermediate in the biosynthesis of many carotenoids, including beta-carotene, which is responsible for pigmentation, photosynthesis, and photo-protection. Lycopene's eleven conjugated double bonds give it its deep red color and are responsible for its antioxidant activity. When absorbed from the stomach, lycopene is transported in the blood by various lipoproteins and accumulates in the liver, adrenal glands, prostate and testes (Nahum et al; 2001). Of all the carotenoids, lycopene is one of the most potent antioxidants; particularly able to quench singlet oxygen and peroxyl radicals, both of which are thought to be responsible for damaging DNA in a process which can lead to the initiation of cancer. Because of this ability, lycopene is being investigated as a potential agent for the prevention of some types of cancers, particularly prostate cancer (Di Mascio, et al; 1989). Lycopene protects against oxidative damage to lipids, proteins, and DNA. Lycopene is a potent quencher of singlet oxygen (a reactive form of oxygen), which suggests that it may have comparatively stronger antioxidant properties than other major plasma carotenoids. Lycopene induces Phase II enzymes which help to eliminate carcinogens and toxins from the body (Ben-Dor et al 2001).

Aim of work:

Our study aimed to investigate the role of lycopene as antioxidant in improving the oxidative stress induced by boldenone in male albino rats.

\section{MATERIALS AND METHODS}

\subsection{Experimental animals and dosing}

Twenty eight apparently healthy male Wister albino rats weighed 125-160 gm obtained from Veterinary National Research Institute, Cairo, Egypt, were randomly divided into 4 groups each one contains 7 rats. $1^{\text {st }}$ group (control) includes animals that injected intramuscularly with olive oil once a week. $2^{\text {nd }}$ group was rats received lycopene daily (orally, $60 \mathrm{mg} / \mathrm{kg}$ body weight)-obtained from Al Debeiky pharmaceuitical companyaccording to (Sönmex et al., 2011). $3^{\text {rd }}$ group includes animals that received intramuscular injections of boldenone once a week (5 $\mathrm{mg} / \mathrm{Kg}$ body weight) - obtained from Swiss labs- according to (Gabr, et al., 2009). $4^{\text {th }}$ 
group was co-treated with boldenone (intramuscular injections, $5 \mathrm{mg} / \mathrm{Kg}$ body weight) plus lycopene (orally, $60 \mathrm{mg} / \mathrm{kg}$ body weight). The experiment was extended for 5 weeks.

2.2. Performance and growth measurement

Mean body weight was estimated every week, while the body gain was calculated according to (Broody; 1945).

\subsection{Sampling}

Serum obtained by blood collection after the end of experiment by 24 hours from the inner canth of eye in non-heparinized dry clean centrifuge tube then centrifugation, the serum was kept at $-20^{\circ} \mathrm{C}$ till used in the evaluation of biochemical studies. Tissue samples (liver, heart and skeletal muscle) were collected after the end of experiment by 24 hours and fixed in $10 \%$ formalin for histopathological studies. part of skeletal muscle kept in $-80^{\circ}$ for total protein electrophoresis.

2.4. serum Biochemical parameters:

Total protein, was determined calorimetrically according to Gornall, et al; (1949), albumin, was determined calorimetrically according to Doumas, et al., (1971), globulin is calculated as (total protein - albumin= globulin), A/G ratio is calculated

\section{RESULTS}

Body weight showed a significant increase from $1^{\text {th }}$ week till $4^{\text {th }}$ week in the Boldenone group when compared with control group and Lycopene group. While there was significant decrease in the body weight of treated group which received Lycopene plus Boldenone in compared with the boldenone group (Table 1) .

Regarding the result of total protein, albumin, globulin and albumin/globulin (A/G) ratio, non-significance change in was detected in Lycopene group compared to control group. While, there was significant increase in total protein and globulin and significant decrease in albumin and $\mathrm{A} / \mathrm{G}$ ratio as (albumin $\div$ globulin), Antioxidant enzyme activity: MDA was determined by the reaction described by ohkawa et al; (1979), SOD was performed according to Oyanagui, (1984). CK and LDH enzymes concentrations are determined and measured according to Burtis, et al; (2005).

2.5. Determination of total protein skeletal muscle by electrophoresis:

The method used for electrophoresis was that of Davis, (1964).

The electropherogram calculated according to SynGene S. No.17292*14518 sme*mpcs.

2.6. Histopathological examination:

Autopsy samples were taken from the liver, heart and skeletal muscle in different groups of rats and used for histopathological examination using $\mathrm{H} \& \mathrm{E}$ stain according to Banchroft et al., (1996).

2.7. Statistical analysis:

Data were statically analyzed by using the statistical software package SPSS for windows (Version 16). The significance of differences between more than two groups was evaluated by one way analysis of variance (ANOVA) using DUNCAN as posthoc test according to spss1nc. Chicago, USA.

in Boldenone group compared to control group and Lycopene group. The result of cotreated group (Lycopene + Boldenone) showed amelioration in in comparison with other groups (Table 2).

The result of MDA and SOD showed no significant changes in lycopene group compared to control group. In Boldenone group, the results showed significant increase in MDA and significant decrease in SOD in compared to control and lycopene groups, but in co-treated group (Lycopene + Boldenone) the amelioration effect of lycopene is more clear (Table 3).

Regarding the results of $\mathrm{LDH}$ and CK showed non-significant changes in lycopene 
group compared to control group, while the results of boldenone group compared to control and lycopene groups showed significant increase in LDH and CK. But, the results of co- treated group (Lycopene + Boldenone) were ameliorated when compared to others groups (Table 4).

There was no significant change in total protein of skeletal muscles in Lycopene group compared to control group. While, there was significant increase in total protein of skeletal muscles in Boldenone group compared to control and Lycopene groups. But, the results of treated group (Lycopene + Boldenone) were ameliorated when compared to others groups (Table 5).

Histopathological examination of liver, heart and skeletal muscles of rats in control, Lycopene and (Lycopene + Boldenone) groups, showed the normal histopathological structure of examined organs and no histopathological alterations after 5 weeks of the experiment photos (1-3). But in BOL group rats showed histopathological changes after 5 weeks of the experiment, this changes as follows:- In heart, sever dilatation in myocardial blood capillaries associated with focal haemorrages in between myocardial bundles photo 2 (c, d). In skeletal muscles showed focal hyalinization some of the bundles associated with corrugation in the outside of some others. Photo 3 (c, d). In the liver focal necrosis was detected in the hepatic parenchyma associated with dilatation in the central vein as well as fatty change in the surrounding adjacent hepatocytes, the portal area showed inflammatory cells infiltration and few fibroblastic cells proliferation photo 1 (c, d, e and f). On other hand, there is a markedly ameliorative effect in the group received (Lycopene + Boldenone) compared with Boldenone group as the histopathological photo 1 (g), photo 2 (e) and photo 3 (e) showed no histopathological alternations in liver and skeletal muscles tissues, but in heart showed only a mild dilatation in the myocardial blood capillaries.

Table (1): Effect of Lycopene and/or Boldenone Undecylenate on body weight (gm) (Mean \pm SE) $(\mathrm{N}=5)$.

\begin{tabular}{lccccc}
\hline \multirow{2}{*}{ Group } & Before & \multicolumn{4}{c}{ After treatment $($ week $)(\mathrm{gm})$} \\
\cline { 3 - 6 } & treatment & $1^{\text {st }}$ & $2^{\text {nd }}$ & $3^{\text {rd }}$ & $4^{\text {th }}$ \\
Control & $127.8 \pm 2.91^{\mathrm{a}}$ & $121.4 \pm 1.94^{\mathrm{c}}$ & $119.2 \pm 2.92^{\mathrm{d}}$ & $117.0 \pm 4.05^{\mathrm{c}}$ & $115.4 \pm 2.77^{\mathrm{d}}$ \\
Lycopene(LYCO) & $130.8 \pm 2.75^{\mathrm{a}}$ & $135.4 \pm 2.96^{\mathrm{b}}$ & $145.6 \pm 3.56^{\mathrm{c}}$ & $159.4 \pm 8.43^{\mathrm{b}}$ & $173.2 \pm 15.40^{\mathrm{c}}$ \\
Boldenone(BOL) & $130.8 \pm 2.52^{\mathrm{a}}$ & $162.4 \pm 7.58^{\mathrm{a}}$ & $182.6 \pm 6.11^{\mathrm{a}}$ & $184.4 \pm 6.81^{\mathrm{a}}$ & $195.4 \pm 6.93^{\mathrm{a}}$ \\
BOL+LYCO & $128.6 \pm 0.93^{\mathrm{a}}$ & $160.8 \pm 2.71^{\mathrm{a}}$ & $171.6 \pm 3.85^{\mathrm{b}}$ & $179.6 \pm 4.23^{\mathrm{a}}$ & $187.4 \pm 5.41^{\mathrm{b}}$ \\
\hline
\end{tabular}

Mean with different superscript letters at the same row are significantly different at $(P<0.05)$. 
Table (2): Effect of Lycopene and/or Boldenone Undecylenate on total protein, albumin, globulin and $\mathrm{A} / \mathrm{G}$ ratio (mean $\pm \mathrm{SE})(\mathrm{N}=5)$.

\begin{tabular}{lcccc}
\hline Group & $\begin{array}{c}\text { Total } \\
\text { protein }(\mathrm{g} / \mathrm{dl})\end{array}$ & Albumin $(\mathrm{g} / \mathrm{dl})$ & Globulin(g/dl) & A/G ratio(\%) \\
Control & $4.95 \pm 0.07^{\mathrm{c}}$ & $4.03 \pm 0.22^{\mathrm{a}}$ & $0.91 \pm 0.20^{\mathrm{b}}$ & $4.42 \pm 1.49^{\mathrm{a}}$ \\
Lycopene(LYCO) & $5.69 \pm 0.13 \mathrm{~b}^{\mathrm{c}}$ & $3.78 \pm 0.15^{\mathrm{a}}$ & $1.91 \pm 0.25^{\mathrm{b}}$ & $1.98 \pm 0.50^{\mathrm{b}}$ \\
Boldenone(BOL) & $7.16 \pm 0.20^{\mathrm{a}}$ & $3.13 \pm 0.41^{\mathrm{a}}$ & $4.03 \pm 0.38^{\mathrm{a}}$ & $0.77 \pm 0.24^{\mathrm{b}}$ \\
BOL+LYCO & $6.66 \pm 0.76^{\mathrm{ab}}$ & $3.61 \pm 0.32^{\mathrm{a}}$ & $3.05 \pm 0.50^{\mathrm{a}}$ & $1.18 \pm 0.15^{\mathrm{b}}$ \\
\hline
\end{tabular}

Mean with different superscript letters at the same row are significantly different at $(\mathrm{P}<0.05)$.

Table (3): Effect of Lycopene and/or Boldenone Undecylenate on MDA and SOD (mean \pm SE) $(\mathrm{N}=5)$.

\begin{tabular}{lll}
\hline Group & MDA $(\mathrm{nmol} / \mathrm{ml})$ & SOD $(\mathrm{u} / \mathrm{ml})$ \\
Control & $1.95 \pm 0.22^{\mathrm{b}}$ & $156.25 \pm 22.45^{\mathrm{a}}$ \\
Lycopene(LYCO) & $2.62 \pm 0.60^{\mathrm{ab}}$ & $178.40 \pm 25.53^{\mathrm{a}}$ \\
Boldenone(BOL) & $3.34 \pm 0.20^{\mathrm{a}}$ & $73.63 \pm 10.29^{\mathrm{b}}$ \\
BOL+LYCO & $2.46 \pm 0.10^{\mathrm{ab}}$ & $101.00 \pm 4.72^{\mathrm{b}}$ \\
\hline
\end{tabular}

Mean with different superscript letters at the same row are significantly different at $(P<0.05)$.

Table (4): Effect of Lycopene and/or Boldenone Undecylenate on LDH and CK (mean \pm SE) (N=5).

\begin{tabular}{lcc}
\hline Group & $\mathrm{LDH}(\mathrm{u} / \mathrm{l})$ & $\mathrm{CK}(\mathrm{u} / \mathrm{l})$ \\
Control & $837.40 \pm 82.50^{\mathrm{b}}$ & $449.60 \pm 131.11^{\mathrm{b}}$ \\
Lycopene(LYCO) & $826.00 \pm 73.00^{\mathrm{b}}$ & $356.00 \pm 62.86^{\mathrm{b}}$ \\
Boldenone(BOL) & $1055.80 \pm 7.00^{\mathrm{a}}$ & $905.80 \pm 12.78^{\mathrm{a}}$ \\
BOL+LYCO & $919.20 \pm 69.18^{\mathrm{ab}}$ & $756.80 \pm 123.20^{\mathrm{a}}$ \\
\hline
\end{tabular}

Mean with different superscript letters at the same row are significantly different at $(P<0.05)$.

Table (5): Effect of Lycopene and/or Boldenone Undecylenate on total protein in tissues (skeletal muscles) (mean $\pm \mathrm{SE})(\mathrm{N}=5)$.

\begin{tabular}{lc}
\hline Group & Total protein $(\mathrm{g} / \mathrm{dl})$ \\
Control & $1.20 \pm 0.06^{\mathrm{b}}$ \\
Lycopene(LYCO) & $1.32 \pm 0.29^{\mathrm{b}}$ \\
Boldenone(BOL) & $2.53 \pm 0.20^{\mathrm{a}}$ \\
BOL+LYCO & $1.53 \pm 0.10^{\mathrm{b}}$ \\
\hline
\end{tabular}

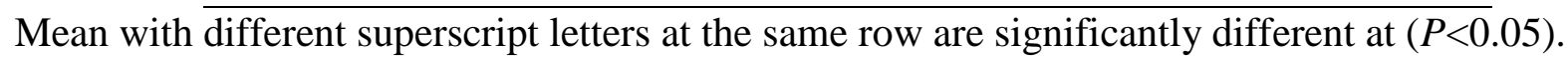


Photo (1) Liver

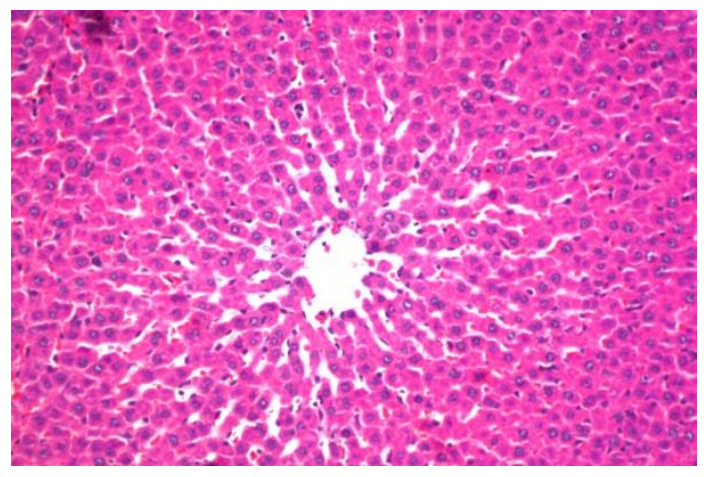

photo (a): Liver of rat in control group showing the normal histological structure of the central vein and surrounding hepatocytes in the hepatic parenchyma H\&E (X 40).

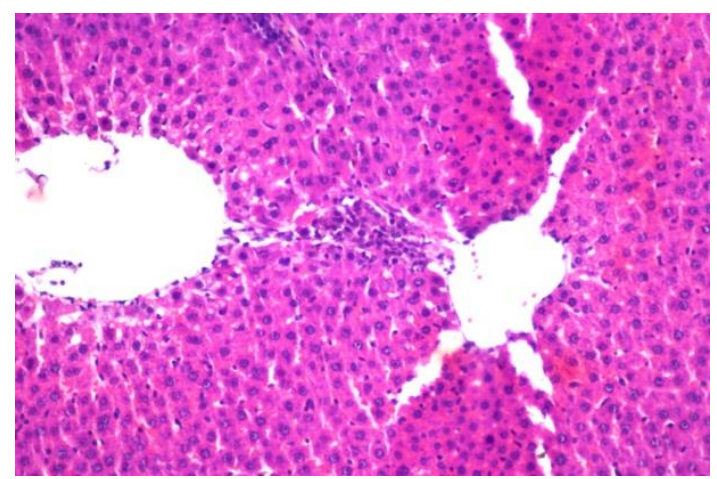

Photo (c): Liver of rat in boldenone group showing dilatation in central vein $\mathrm{H} \& \mathrm{E}(\mathrm{X}$ 40).

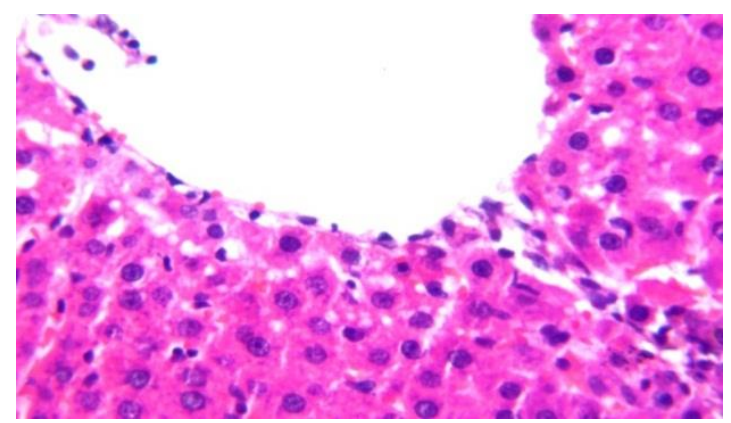

Photo (e): Liver of rat in boldenone group showing mild fatty change in hepatocytes surrounding the dilated central vein $H \& E$ (X 80).

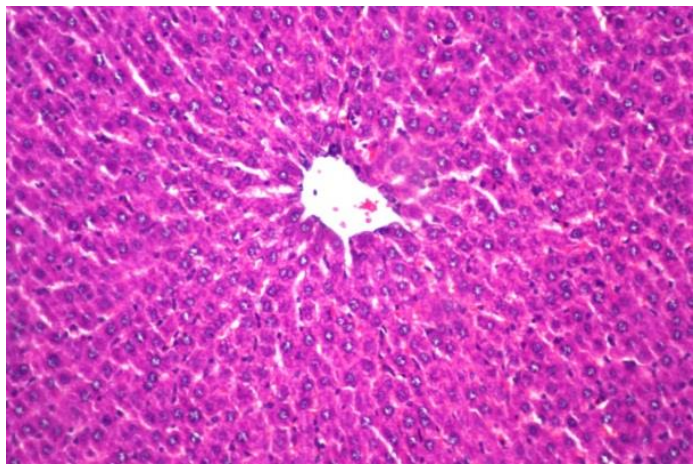

Photo (b): Liver of rat in lycopene group showing the normal histological structure H\&E (X 40).

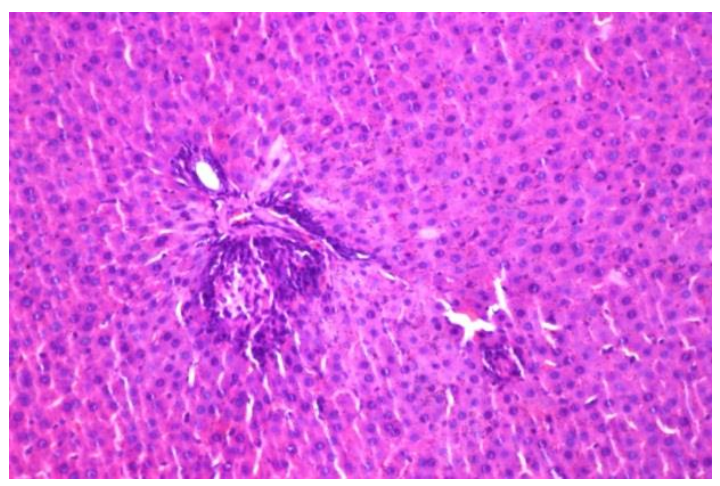

Photo (d): Liver of rat in boldenone group showing focal necrosis in hepatic parenchyma H\&E (X 40).

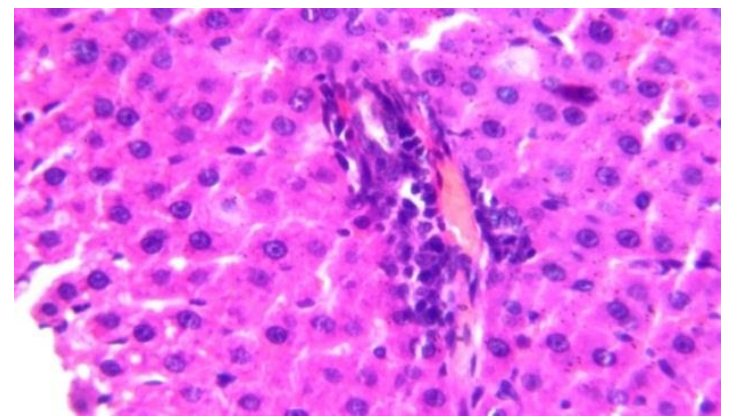

Photo (f): Liver of rat in boldenone group showing inflammatory cells infiltrations in the portal area $H \& E(X 80)$. 


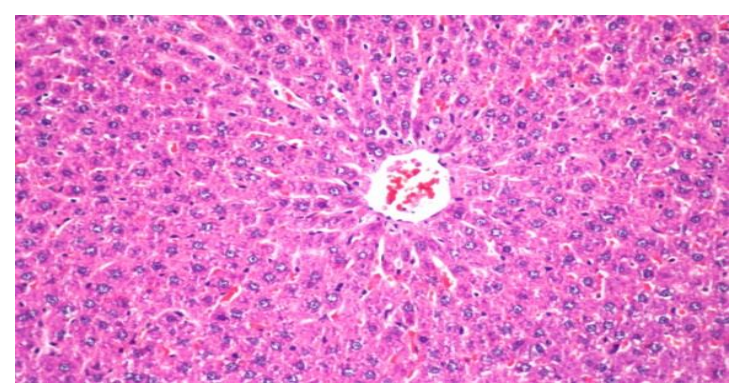

Photo (g): Liver of rat in lycopene plus boldenone group showing the normal histological structure H\&E (X 40).

Photo (2) Heart

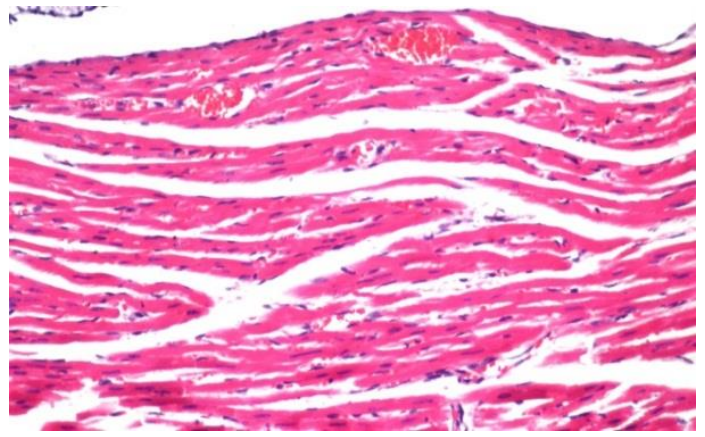

Photo (a): Heart of rat in control group showing normal histological structure of myocardial bundles H\&E (X 40).

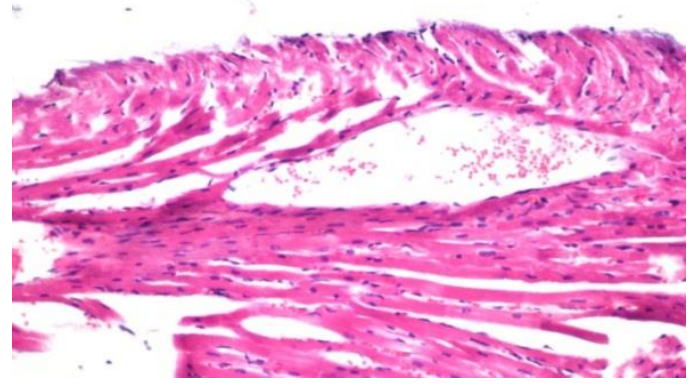

Photo (c): Hearts of rat in boldenone group showing sever dilatation in cardiac blood vessels in myocardium $\mathrm{H} \& \mathrm{E}$ (X 40).

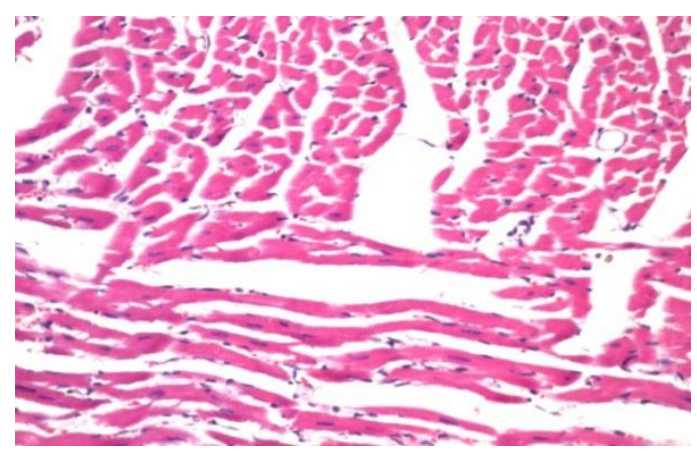

Photo (b): Heart of rat in lycopene group showing normal histological structure of myocardium H\&E (X 40).

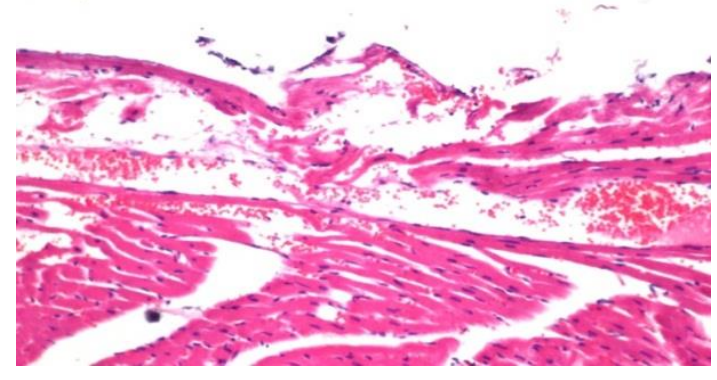

Photo (d): Heart of rat in boldenone group showing hemorrhage in between myocardial bundles H\&E (X 40). 


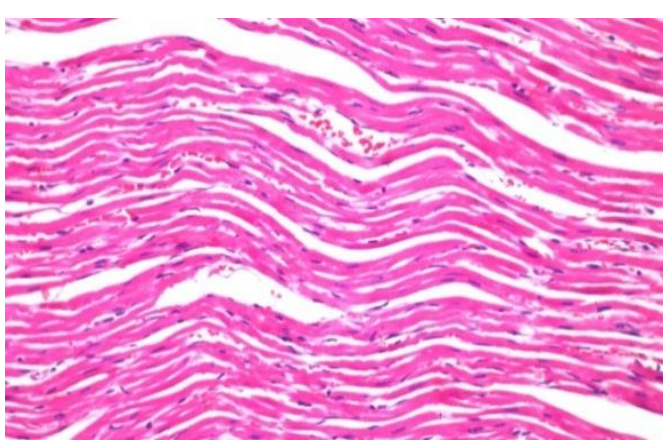

Photo (e): Heart of rat in lycopene plus boldenone group showing mild dilatation in myocardial blood capillaries H\&E (X 40).

Photo (3) Skeletal muscle

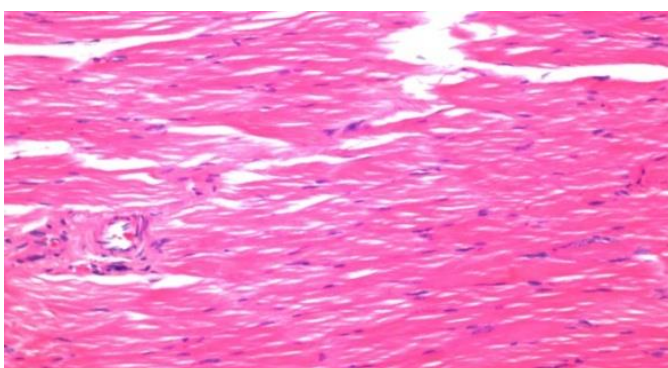

Photo (a): Skeletal muscle of rat in control group showing normal histological structure as normal striated muscle bundles H\&E (X 40).

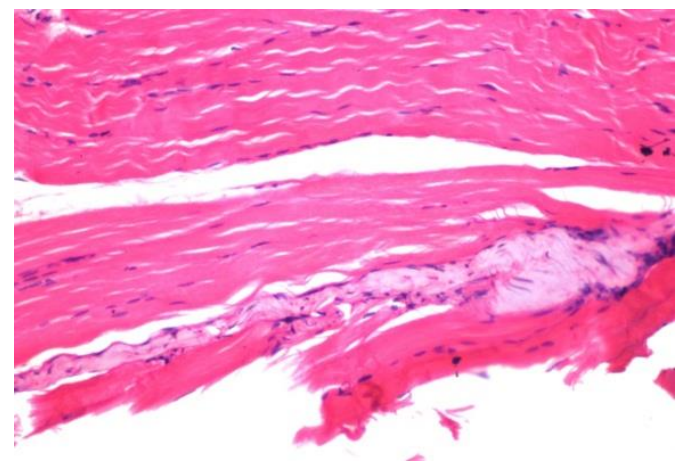

Photo (c): Skeletal muscle of boldenone group showing focal hyalinization of some skeletal muscle bundles H\&E (X 40).

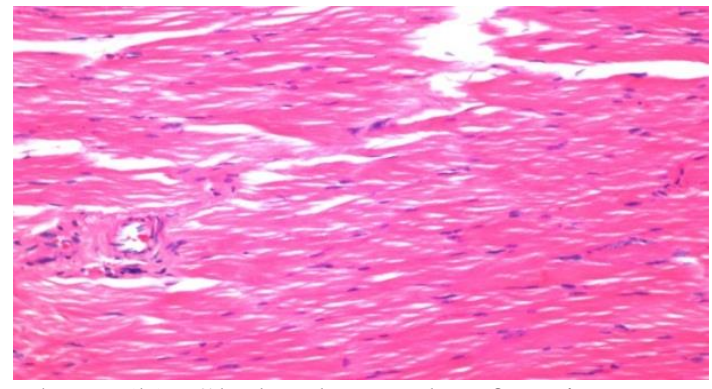

Photo (b): Skeletal muscle of rat in lycopene group showing normal histological structure H\&E (X 40).

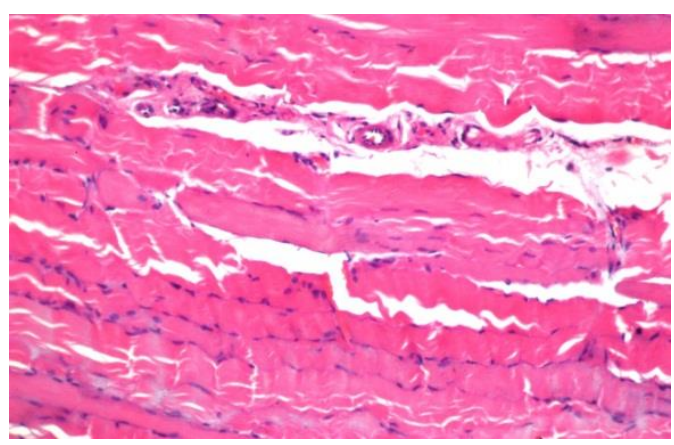

Photo (d): Skeletal muscle of boldenone group showing corrugations in outer line of muscle bundles H\&E (X 40).

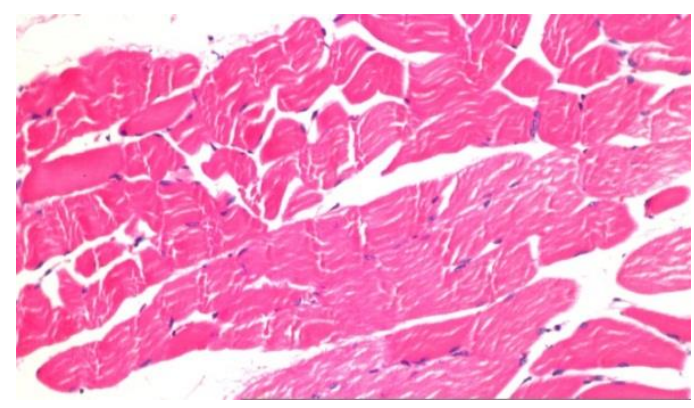

Photo (e): Skeletal muscle of rat in lycopene plus boldenone group showing normal histological structure H\&E (X 40). 


\section{DISCUSSION}

Boldenone undecylenate one of AAS used to improvement of the growth and food conversion in food producing animals. The anabolic effects of AAS promote protein synthesis, muscle growth and erythropoiesis (Soma, et al., 2007). Hence, AAS are used to enhance strength and durability of canine, equine and human athletes (Matinhomae, et al., 2014). Our study aimed to investigate the role of lycopene as antioxidant in improving the oxidative stress induced by boldenone in male albino rats.

Our results revealed that injection of the anabolic steroid BOL to albino male rats evoked a significant increase in growth rate as indicated by a significant increase in total weight gain (TWG), similar findings were reported by (Saleh and Waded, 2014) and This effect could be attributed to the fact that BOL act upon the androgen receptors in anabolic-responsive tissues promoting the body tissue building processes due to increased protein synthesis. This is achieved by converting the negative nitrogen balance into a positive one through improving the use of ingested proteins and increasing nitrogen retention and animal's appetite (Falanga et al., 1998). Others reported that anabolic hormones can increase the cellular protein biosynthesis indirectly via stimulation of growth hormone and insulin like growth factor secretion (Arnold et al., 1996). Furthermore, it was also assumed that AAS reduce recovery time by blocking the effects of stress hormone cortisol on muscle tissue, so that catabolism of muscle is greatly reduced (Sauerwein et al; 1991).

Although hypo- proteinemia is an established finding in liver damage (Larrey, 2002), given that the liver creates most plasma-protein fractions, here, the total plasma protein and globulin concentrations were significantly increased after boldenone administration. These findings could be attributed to the nitrogen-retention capacity of the drug. Additionally, the increment of globulins may be attributed to the increased $\alpha$ - and $\beta$-fractions rather than the $\gamma$-fractions, including positive acute-phase proteins. Albumin, in contrast, is considered a negative acute-phase protein that is decreased in inflammation, especially hepatic. Although the calculated albumin/globulin ratio was decreased, albumin concentrations showed insignificant changes in our study and this result was in agreement with (Abdelrazzag, et al., 2016). Total protein significantly increased with the BOL injection due as mentioned previously to the multifactorial effects of BOL on the protein metabolism (ElSayed and Kerdasy, 2007). Our data confirmed by the histopthology of liver of BOL group showed that rats that received five doses of boldenone revealed focal necrosis was detected in the hepatic parenchyma associated with dilatation in the central vein as well as fatty change in the surrounding adjacent hepatocytes, the portal area showed inflammatory cells infiltration and few fibroblastic cells proliferation in liver photo1 (c, d, e, f).

Elevated levels of CK and LDH in this study indicated an adverse effect of boldenone on cardiac and/or skeletal muscle. This confirmed by histopathological abnormalities in heart and skeketal muscles in BOL group. In heart, sever dilatation in myocardial blood capillaries associated with focal haemorrages in between myocardial bundles photo2 (c- d). In skeletal muscles showed focal hyalinization some of the bundles associated with corrugation in the outside of some others photo 3 (c-d). Multiple investigations reported that boldenone abuse was associated with occurrences of serious cardiovascular events in young athletes, 
including development of cardiomyopathy, atrial fibrillation, infarction, disturbances of hemostatic system, and ventricular thrombosis (Hartgens and Kuipers, 2004). On other hand, there is a markedly ameliorative effect in the group received lycopene plus BOL compared with BOL group as the histopathological pictures showed no histopathological alternation in the skeletal muscles tissue photo3 (e), and showed a mild dilatation in the myocardial blood capillaries photo2 (e).

Oxidative stress has been defined as a disturbance in the balance between antioxidants and pro-oxidants (free radicals and other reactive species) with increased levels of pro-oxidants leading to potential damage. This imbalance can be an effect of depletion of endogenous antioxidants, low dietary intake of antioxidants and/or increased formation of free radicals and other reactive species. In human tissues, a condition of oxidative stress can be revealed through searching for specific biomarkers of oxidative damage to lipids, proteins and nucleic acids (Zhang, et al., 2009). BOL treatment can cause an oxidative stress situation in liver as indicated by enhanced MDA activity (increased MDA concentration). Interestingly, reactive oxygen species (ROS) and MDA have been implicated in the pathogenesis of many types of liver injury and especially in the hepatic damage induced by several toxic drugs (Uchida, et al; 1999). Our results are in agreement with (Lamiaa et al; 2015) who reported that a significant increase in the MDA, NO, GSH, total protein, total thiol and catalase and significant decreased in cotreated boldenone with propolis in rat liver and kidney when compared to the boldenone group. In the current study; decrease in the activities of antioxidant enzymes SOD can be explained either with their induction during the conversion of free radicals into inactive metabolites or secondarily with the direct inhibitory effect of boldenone on enzymes activities. Our results are in agreement with (Mayada, et al., 2015) who reported that Intramuscular injection of BOL increased malondialdehyde (MDA) level, but markedly lowered activities of superoxide dismutase (SOD) and the findings of (El-Moghazy et al. 2012) who reported that BOL injection in rabbits caused hepatic oxidative stress. These findings are also concordant with previous studies by (Sadowska-Krepa et al. 2011), where they cited that AAS treatment induced oxidative stress in rats. Our data confirmed the histopthology of liver of BOL group showed that rats that received five doses of boldenone revealed focal necrosis was detected in the hepatic parenchyma associated with dilatation in the central vein as well as fatty change in the surrounding adjacent hepatocytes, the portal area showed inflammatory cells infiltration and few fibroblastic cells proliferation in liver photo1 (c, d, e,f). Interestingly, the ameliorative effect of lycopene against effect of BOL on MDA and SOD is clearly observed. MDA level was reduced and SOD was elevated, this was in comparison between co- treated group (LYCO plus BOL) and BOL group, this ameliorative effect in the group received lycopene plus BOL confirmed by the histopathological Photo1 (g) showed no histopathological alternation in liver.

In our study, total protein in skeletal muscles was significantly increased, this was attributed to the mechanism of action of boldenone steroid hormones work by stimulation of receptors molecule in muscle cells, which activate specific genes to produce proteins. They also affect the activation rate of enzyme system involved in protein mechanism. Thus enhancing protein synthesis and inhibiting protein degradation (Mottram and George, 2000). Also BOL increases muscle size owing to promotion of positive nitrogen balance by stimulating protein 
production and reducing protein destruction, as well as causing retention of body water, nitrogen, sodium, and potassium and calcium ions (Tousson, et al., 2012b). Our result confirmed by histopathological abnormalities in skeketal muscles photo 3 (c,d) in BOL group showed focal hyalinization some of the bundles associated with corrugation in the outside of some others. But there is a markedly ameliorative effect in the group received lycopene plus BOL compared with BOL group as the histopathological pictures showed no histopathological alternation in skeketal muscles photo3 (e). Our histopathology study was in agreement with (Tousson, 2013) who reported that rabbits that received BOL showed hypertrophy, nuclear pycnosis and cytoplasmic vacuoles in both skeletal and cardiac muscles, disturbances of the hepatocytes radially arranged cords with multifocal hepatocellular vacuolations in the liver.

\section{CONCLUSION}

This study concluded that the Boldenone is one of steroidal substance induce increase of body weight, changes in haemopiotic system and hepatotoxicity also, it concluded that lycopene has protective effect against Boldenone toxicity, as it showed marked improvement in haematological alterations and oxidative changes in liver, heart and skeletal muscle.

\section{REFERENCES}

Abdelrazzag Elmajdoub, Aboubaker Garbaj, Said Abolghait, Abubakr ElMahmoudy, (2016): Evaluation of boldenone as a growth promoter in broilers: safety and meat quality aspects, science direct 24284 e 292.

Arnold AM, Peralta JM, Thonney ML. (1996): Ontogeny of growth hormone, insulin-like growth factor-I, estradiol and cortisol in the growing lamb: effect of testosterone. J Endocrinol.; 150(3):391-9.

Banchroft, J.D. Stevens, A. And Turner, D.R. (1996): Theory And Practice Of Histological Techniques. Fourth Ed. Churchil Livingstone, New York, London, San Francisco, Tokyo.

Ben-Dor A, Nahum A, Danilenko M, Giat Y, Stahl W, Martin HD, Emmerich T, Noy N, Levy J, Sharoni Y; (2001): Effects of acyclo-retinoic acid and lycopene on activation of the retinoic acid receptor and proliferation of mammary cancer cells. Arch Biochem Biophys; 391(1):295-302.

Britton G. (1995): Structure and properties of carotenoids in relation to function. FASEB J; 9: 1551-8.

Broody, S. (1945): Bioenergetis and Growth Reinhold pub Crop. New york.

Burtis CA, Ashwood ER, Bruns DE, WB Saunders Co, (2005): Tietz Textbook of Clinical Chemistry and Molecular Diagnosis, $4^{\text {th }}$ ed.

Cannizzo, T.F., Zancanaro, G., Spada, F., Mulasso, C. and Biolatti, B. (2007): Pathology of the testicle and sex accessory glands following the administration of boldenone and boldione as growth promoters in veal calves. J. Vet. Med. Sci., 69: 11091116.

Chitra, KC. Latchoumycandane, C. and Mathur, pp. (1999): chronic-effect of endosulfan on the testicular functions of rat. Asian J Androle; 1:203-6.

Davis, B. (1964): Disk electrophoresis. II Method and application to human serum protein. Annual of New York Academy Science, 929: 404-427.

De Brabander, H.F., Poelmans, S., Schilt, R., Stephany, R.W., Le Bizec, B.,Draisci, R., Sterk, S.S., van Ginkel, L.A., Courtheyn, D., Van Hoof, N., Macrì, A.and De Wasch,K. (2004): Presence 
and metabolism of the anabolic steroid boldenone in various animal species: a review. Food Additives and Contaminants. 21 (6): 515-525.

Di Mascio P, Kaiser S, Sies H. 1989: Lycopene as the most efficient biological carotenoid singlet oxygen quencher. Arch Biochem. Biophys.; 274(2):532-538.

Doumas, BT, ArdWatson W, and Biggs HG, (1971): Albumin standards and the measurement of serum albumin with bromcresol green. Clin. Chim. Acta. Jan; 31:87-96.

El-Moghazy M, Tousson E, Sakeran M (2012): Changes in the hepatic and renal structure and function after a growth promoter boldenone injection in rabbits. Animal Biochemistry 62:171180.

El-Sayed MG, Kerdasy AF. (2007): The effects of the anabolic steroid (boldenone undecylenate) in castrated males, non-castrated males and nonpregnant females of goats. ZAG. Vet. J.; 35(1):172-82.

Falanga V, Greenberg A, Zhou L.(1998): Stimulation of collagen synthesis by the anabolic steroid stanozolol. J Invest Dermatol.; 11(6):1193-97.

Gabr F, Abo El-Maaty T, Amal M, Aotifa A. (2009): Effects of growth promoter boldenone undecylenate on weaned male lambs. Nature and Science; 7:619.

Gornall AG, Bardawill CJ, David MM. (1949): Determination of serum proteins by means of the biuret reaction. $\mathrm{J}$ Biol Chem. Feb; 177:751-66.

Hartgens F, Kuipers H. (2004): Effects of androgenic-anabolic steroids in athletes. Sports Med; 34:513 e54.
Lamiaa A. A. Barakat, Ehab Tousson, Wafaa Ibrahim, Aya Abd El-Hakeem (2015): Role of Propolis in Improving Hepatic and Renal Damage in Boldenone Undecylenate in Male Rats. International Journal of Public Health Research. Vol. 3, No. 1, pp. 8-15.

Larrey D, (2002): editor. Epidemiology and individual susceptibility to adverse drug reactions affecting the liver. Seminars in liver Disease. New York.

Matinhomaee H, Ziaolhagh SJ, Azarbayjani MA, Piri M. (2014): Effects of Boldenone consumption and resistance exercise on hepatocyte morphologic damages in male wistar rats. Eur J Exp Biol; 4:211e.

Mayada R.F., Taghred M.S., Haytham a.a. (2015): Boldenone-induced apoptotic, structural, and functional alterations in the liver of rabbits World Rabbit Sci., 23: 39-46.

Mottram, D.R. and George A.J. (2000): Anabolic steroids. Best Practice \& Research Clinical Endocrinology \& Metabolism. 14 (P): 55-69.

Nahum A, Hirsch K, Danilenko M, Watts CK, Prall OW, Levy J, Sharoni Y; (2001): Lycopene inhibition of cell cycle progression in breast and endometrial cancer cells is associated with reduction in cyclin $\mathrm{D}$ levels and retention of p27(Kip1) in the cyclin Ecdk2 complexes. Oncogene; 20(26):3428-3436.

Ohkawa, H., Ohishi W, and Yagi K. (1979): Anal. Biochem 95, 351.

Oyanagui,Y., (1984): Reevaluation Of Assay Methods And Establishment Of Kit For Superoxide Dismutase Ativity. Anal. Biochem., 142:290-296.

Sadowska-Krepa E., Kłapcińska B., Jagsz S., Sobczak A., Chrapusta S.J., Chalimoniuk M., Grieb P., Proprzęcki. S., Langfort J. (2011): High-Dose 
Testosterone Propionate Treatment

Reverses the Effects of Endurance

Training on Myocardial Antioxidant

Defenses in Adolescent Male Rats.

Cardiovasc. Toxicol, 11: 118-127.

Saleh N. and Waded E. (2014): Immune response following the administration of the anabolic steroid Boldenone Undecylenate in rabbits. Stem Cell; 5:80 e 7.

Sauerwein H, Diirsch I, Meyer H. (1991): Quantitation of glucocorticoid receptors in bovine skeletal muscle: topographical distribution, sex effect and breed comparisons. J Steroid Biochem.; 39:941-45.

Shahidi NT. (2001): A review of the chemistry, biological action and clinical applications of anabolic-androgenic steroids. Clin. Therapeutics. 23:13551390.

Soma, L.R., C.E. Uboh, F. Guan, S. MCDonnell and J. Pack, (2007): Pharmacokinetics of boldenone and stanozolol and the results of quantification of anabolic and androgenic steroids in race horses and non-race horses. J. of Veterinary Pharmacology and Therapeutics. 30: 101-108.

Sönmex M, Turk G, Cerbasi AO, Sakin F, Atessahin A. (2011): Attenuating effect Of lycopene And ellagic Acid On 2, 3, 7, 8-tetrachlorodibenzo-p-dioxinInduced spermiotoxicity And testicular apoptosis. Drug Chem Toxicol; 34: 347-356.

Tousson E. (2013): Histopathological alterations after a growth promoter boldenone injection in rabbits. Toxicology and Health; 32:299 e 305.

Tousson, E., El-Moghazy, M., Massoud, A. and Akela M., (2012a): Histopathological and immunohistochemical changes in the testis of rabbits after injection with the growth promoter boldenone. Reprod. Sci., 19: 253-259.

Tousson, E., El-Moghazy, M., Massoud, A. and Sakeran, M. (2012b): Changes in hepatic and renal structure and function after a growth promoter boldenone injection in rabbits. 62: 171-180.

Uchida, M., Shiraishi, K., Naito, Y., Torii, Y., Nakamura, Y. and Osawa, T. (1999): Activation of stress signaling pathways by the end product of lipid peroxidation. 4-Hydroxy-2-nonenal is a potential inducer of intracellular peroxide production, J. Biol. Chem. 274, 2234- 2242.

Zedan NS, Tousson E, Massoud A and ElSaeed A. (2014): Biochemical and histopathological alterations in rattestes after injection with the growth promoter Equigan with reference to the ameliorating role of Proplis. $2^{\text {nd }}$ International Conference for Nutrition and Growth, Barcelona, Spain.

Zhang, X.L., Yang, Y.S., Ping, D., Hui, J., Zhou, M Gong, Y. and Huang, J. (2009): Comparative Study on Overexpression of HER2/neu and HER3 in Gastric Cancer. World Journal of Surgery. 33: 2112-2118. 